\title{
Distribution and Behaviour of Nitrogen Compounds in the Surface Water of Sungai Terengganu Estuary, Southern Waters of South China Sea, Malaysia \\ (Taburan dan Perlakuan Sebatian Nitrogen di Permukaan Air Muara Sungai Terengganu, Perairan Selatan Laut China Selatan, Malaysia)
}

Suhaimi Suratman*, Azyyati Abdul Aziz, Norhayati Mohd TAhiR \& LeE Hin LeE

\section{ABSTRACT}

A study was carried out to determine the distribution and behaviour of nitrogen (N) compounds (nitrite, nitrate, ammonia, dissolved and particulate organic nitrogen) in Sungai Terengganu estuary (TRE). Surface water samples were collected during ebb neap and spring tides for the longitudinal survey along the salinity gradient. The results indicated that all $N$ compounds behave non-conservatively with addition during both tidal cycles, except for nitrate which exhibited removal behaviour during spring tide. In general, higher concentration of $N$ compounds was observed during spring tide compared to neap tide. It is suggested that during spring tide, stronger water turbulence resulted in resuspension of nutrients in bottom sediment and lead to the increase in N compounds concentrations in the surface water. The diurnal survey for the freshwater station showed that the concentrations of $N$ compounds follow the ebb and flood variations, whereas for the coastal station the reverse trend was observed. Comparisons with a previous study under similar tidal conditions show there was an increase in nitrite and ammonia concentrations in TRE, which was probably due to increase in discharge from the rapid development activities around this area. In addition, the presence of a breakwater at the lower part of the estuary may also contribute to the high nutrient content in the estuary due to restricted outflow of nutrients to the coastal area. Overall, the results from this study highlighted the importance of monitoring the N compounds for future protection of the estuary.

Keywords: Distribution and behaviour; nitrogen compounds; spring-neap tides; surface water; Sungai Terengganu estuary; surface water

\section{ABSTRAK}

Suatu kajian telah dijalankan untuk menentukan taburan dan perlakuan sebatian nitrogen (N) (nitrit, nitrat, ammonia, nitrogen organik terlarut dan partikulat) di muara Sungai Terengganu (TRE). Sampel permukaan air telah diambil sepanjang cerun saliniti ketika air surut semasa pasang-surut perbani dan purnama. Keputusan kajian menunjukkan semua sebatian $N$ berkelakuan tidak konservatif iaitu tambahan untuk kedua-dua kitaran pasang-surut, kecuali nitrat yang menunjukkan perlakuan singkiran semasa pasang-surut purnama. Secara umumnya, kepekatan sebatian $N$ adalah tinggi semasa pasang-surut purnama berbanding pasang-surut perbani. Adalah dicadangkan semasa pasang-surut purnama, berlakunya kegeloraan air yang kuat menyebabkan nutrien dalam sedimen di dasar sungai akan terampai dan seterusnya meninggikan kepekatan sebatian $N$ di permukaan air. Persampelan diurnal untuk stesen air tawar menunjukkan kepekatan sebatian $N$ mengikut variasi air pasang dan surut, manakala untuk stesen di kawasan pantai, corakyang bertentangan adalah diperhatikan. Perbandingan dengan kajian terdahulu di kawasan dan keadaan pasangsurut yang sama, menunjukkan terdapatnya peningkatan kepekatan nitrit dan ammonia di TRE yang mungkin disebabkan bertambahnya pembuangan daripada aktiviti-aktiviti pembangunan yang pesat di sekitar kawasan kajian. Tambahan lagi, kehadiran benteng pemecah ombak di kawasan hilir muara mungkin turut menyumbang kepada tingginya kandungan nutrien di dalam muara disebabkan pergerakan keluar nutrien ke kawasan pantai yang terhad. Secara keseluruhannya, keputusan daripada kajian ini menekankan kepentingan pemantauan sebatian $N$ untuk pemeliharaan muara sungai pada masa hadapan.

Kata kunci: Muara Sungai Terengganu; pasang surut perbani-purnama; permukaan air; sebatian nitrogen; taburan dan perlakuan

\section{INTRODUCTION}

Nutrient inputs to estuaries, especially nitrogen $(\mathrm{N})$ compunds, have increased significantly globally in tandem with anthropogenic activities (Ismail \& Ibrahim 2015;
Jickells et al. 2014; Statham 2012), which correspond to rising human populations. Elevated nutrient loads generally stimulate primary production in surface water and contribute to the deterioration of water quality. This 
situation can lead to eutrophication problems, hence modifying aquatic food webs and which eventually may lead to hypoxic events (Chen et al. 2012; Driscoll et al. 2012; Garcia et al. 2014). It is noteworthy that variation in nutrient concentrations is not only caused by anthropogenic load but may also be affected by changing tides, which play a major role in controlling the distribution and transport of nutrients in the water column (Gianesella et al. 2005; Senthilkumar et al. 2008; Shaha et al. 2010). Therefore, it is essential to understand the estuarine hydrodynamic processes, such as tidal exchanges in order to monitor the variation of nutrient concentrations in the water column.

Sungai Terengganu estuary (TRE) is situated on the east coast of Peninsular Malaysia that enters the southern front of the South China Sea. The state capital, Kuala Terengganu, is located nearby. This estuary has been a center of economic activities for the local fishermen who use it as a fish landing site and sell their catches. Several anthropogenic activities such as small-scale of fish and seafood processing industries, restaurants, recreation, tourism, boat manufacturing, sand mining and construction activities surround this estuary. Two river systems, namely the Sungai Terengganu and Sungai Nerus, flow into this estuary, carrying many dissolved and particulate constituents.

This study determined the distribution of $\mathrm{N}$ compounds, nitrite, nitrate, ammonia, dissolved organic nitrogen (DON) and particulate organic nitrogen (PON) along the surface water of the estuarine system in the Terengganu River. In addition, tidal influence on the level of $\mathrm{N}$ compounds was also investigated. The behaviour of $\mathrm{N}$ compounds during estuarine mixing was also evaluated using the model as proposed by Liss (1976). Nitrogen has been chosen in this study due to its role as a limiting nutrient in the marine environment (Ryther \& Dunstan 1971; Suratman et al. 2008).

\section{MATERIALS AND METHODS}

Sampling activities were divided into two surveys; the longitudinal survey was performed twice i.e. during spring tide $(22 / 2 / 2012)$ and neap tide (2/4/2012) under similar tidal condition (ebb flow) along the estuary (Figure 1). These two longitudinal surveys were conducted in duration of $4 \mathrm{~h}$ to cover the upstream and downstream stations. Diurnal surveys' were also conducted for a $12 \mathrm{~h}$ tidal cycle, which covered the ebb and flood waters for neap $(12 / 7 / 2012)$ and spring tide (2/9/2012) at two fixed stations i.e. T7 (coastal) and T24 (freshwater).

For both longitudinal and diurnal surveys, surface water samples $(\sim 0.5 \mathrm{~m})$ were collected using a Van Don sampler and stored in acid-washed polyethylene bottles. The samples were placed in an ice cooler and transported back to the laboratory for analysis. About $250-500 \mathrm{~mL}$ samples were filtered through pre-combusted $\left(450^{\circ} \mathrm{C}\right.$ for $5 \mathrm{~h}$ ) and pre-weighed $0.7 \mu \mathrm{m} \mathrm{GF} / \mathrm{F}$ filter immediately upon arrival at the laboratory. The dissolved samples were stored

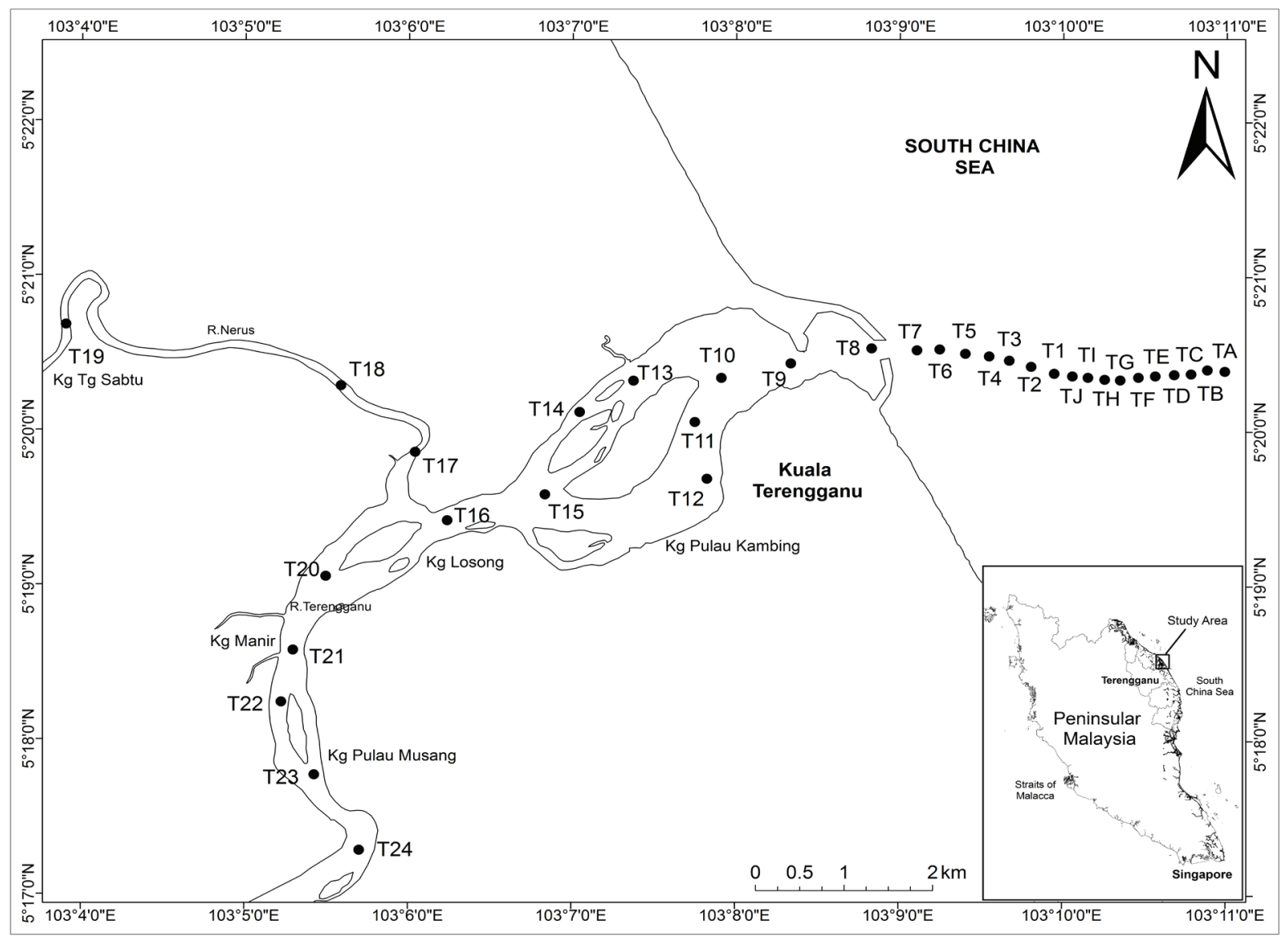

FIGURE 1. Location of sampling stations in Sungai Terengganu estuary 
frozen at $-20^{\circ} \mathrm{C}$ until analysis. The loaded filter papers were kept in a desiccator overnight and then subjected to PON analysis.

Dissolved inorganic nitrogen (DIN) i.e. nitrate, nitrite and ammonia were analysed using a Skalar San Plus Autoanalyzer (Bukaveckas et al. 2011; Sharples et al. 2007; Suratman et al. 2010) and detected spectrophotometrically as a colored complex following standard colorimetric methods described by Grasshoff et al. (1983). Concentration of dissolved organic nitrogen (DON) was calculated by subtraction of DIN from total dissolved nitrogen (TDN) and TDN was measured by high temperature catalytic oxidation (HTCO) method using a Shimadzu TOC-V analyser (Suratman et al. 2008). The filtered samples were injected $(100 \mu \mathrm{L})$ onto a combustion column and heated to $680^{\circ} \mathrm{C}$. TDN in the sample decomposes to nitrogen monoxide and moved down over the catalyst by carrier gas and measured by a chemiluminescence detector. Particulate matter collected on the filter during sample filtration was used for PON determination. The loaded filters were rinsed with deionized water to eliminate the dissolved nutrients and salt. The filters were dried in the oven at $60^{\circ} \mathrm{C}$ for $24 \mathrm{~h}$. Each filter was folded and placed in a tin container and analysed by high temperature oxidation using Themo Electron CHNS Elemental analyser (Flash EA 1112) (Pasquer et al. 2010). In addition, physical parameters such as salinity and dissolved oxygen were also measured in situ using a YSI multiparameter (model 6600) data logger which was calibrated prior to use.

All statistical ANOVA tests were carried out by MS Excel packaged software. Significance degree was accepted as $p<0.05$.

\section{RESULTS AND DISCUSSION}

\section{DISTRIBUTION OF N COMPOUNDS DURING LONGITUDINAL SURVEY}

The longitudinal distribution of $\mathrm{N}$ compounds is presented in Figure 2. However, some stations were not sampled especially during the spring tide due to rough weather. Among the $\mathrm{N}$ compounds, nitrite concentration was found to be the lowest with a range of between 0.02 and $0.23 \mu \mathrm{M}$ (mean $0.11 \pm 0.06 \mu \mathrm{M}$ ). Nitrate concentrations varied from 0.3 to $4.7 \mu \mathrm{M}$ (mean $1.9 \pm 0.9 \mu \mathrm{M}$ ), while concentrations recorded for ammonia and PON ranged between 2.0 and $35.4 \mu \mathrm{M}$ (mean $21.0 \pm 7.8 \mu \mathrm{M}$ ) and 1.5 to $11.8 \mu \mathrm{M}$ (mean $13.9 \pm 2.9 \mu \mathrm{M})$, respectively. The concentration of DON, which is the dominant species of $\mathrm{N}$ compounds in the estuary, range between 3.2 and $40.6 \mu \mathrm{M}$ (mean $24.3 \pm$ $9.4 \mu \mathrm{M})$. In general, the results showed that the concentration of $\mathrm{N}$ compounds in freshwater was higher than in the estuarine environment, thus suggesting that the nutrients are derived mainly from freshwater inputs. It was also observed that the $\mathrm{N}$ compounds in the surface waters were higher during spring tide except for nitrite which showed the contrary. During spring tide, the stronger water turbulence with a high tidal range may have caused stronger bottom mixing, which consequently resulted in an increase in nutrient release from the re-suspended bottom sediment to the surface water. The strong mixing was indicated by higher surface salinity which will bring the bottom nutrient to the surface water. Several studies have showed that the strong turbulence during spring tide leads to sediment resuspension and ultimately to high nutrient release (Anand et al. 2014; Sharples et al. 2007). In addtition, Gilbert et al. (2013) documented that strong current and well mixed water columns during spring tide would result in a more turbid estuary disturbed the sediment and increase the nutrient release.

\section{DISTRIBUTION OF N COMPOUNDS DURING DIURNAL SURVEY}

Figure 3 shows the $12 \mathrm{~h}$ diurnal variation of $\mathrm{N}$ compound measured at station T7 (coastal station) and T24 (freshwater station) for both tides. As observed for the longitudinal survey, nitrite recorded the lowest concentration compared to the other $\mathrm{N}$ compounds and varied from 0.13 to $0.20 \mu \mathrm{M}$ (mean $0.16 \pm 0.03 \mu \mathrm{M}$ ) during spring tide and 0.09 to $0.40 \mu \mathrm{M}$ (mean $0.24 \pm 0.10 \mu \mathrm{M}$ ) during neap tide. The nitrate concentrations were found to range from 1.93 to $2.93 \mu \mathrm{M}$ (mean $2.45 \pm 0.3 \mu \mathrm{M}$ ) during spring tide and 0.55 to $1.44 \mu \mathrm{M}$ (mean $0.55 \pm 0.30 \mu \mathrm{M}$ ) during neap. The ammonia concentrations recorded were higher with a range for spring and neap tides of between 10.6 and $16.3 \mu \mathrm{M}$ (mean $13.8 \pm 1.5 \mu \mathrm{M}$ ) and 5.1 to $15.8 \mu \mathrm{M}$ (mean $0.55 \pm$ $0.30 \mu \mathrm{M})$, respectively. The concentration of PON was in the range of between 23.5 and $29.6 \mu \mathrm{M}$ (mean $24.4 \pm 0.30$ $\mu \mathrm{M}$ ) for spring tide and 25.2 to 28.0 (mean $27.3 \pm 2.0 \mu \mathrm{M}$ ) for neap tide. Among the $\mathrm{N}$ compounds, concentrations of DON were found to be the highest, with a range of between 29.8 and $89.06 \mu \mathrm{M}$ (mean $51.47 \pm 1.59 \mu \mathrm{M})$ during spring tide and 33.4 to $88.06 \mu \mathrm{M}$ (mean $62.5 \pm 18.08 \mu \mathrm{M}$ ) during neap tide. With the exception of PON, concentrations of all $\mathrm{N}$ compounds showed strong correlation with tidal state. Based on the ANOVA test, the mean concentrations of $\mathrm{N}$ compounds during spring tide were found to be significantly higher than during neap tide $(p<0.05)$.

During flooding tide, the flow of seawater into the estuary restricts the movement of freshwater downstream. This situation caused an increase in the concentration of $\mathrm{N}$ compounds at $\mathrm{T} 24$ due to high freshwater input until maximum concentrations were recorded during high water. In contrast, the concentration of $\mathrm{N}$ compounds decrease during ebb water due to free movement of freshwater downstream, which possibly flushed out the nutrients content. Thus, lower levels of $\mathrm{N}$ compounds were recordec during low water. At station T7, located at the coastal area, the reverse trend was observed, where low water recorded higher level of $\mathrm{N}$ compounds and high water recorded low value of $\mathrm{N}$ compounds. This situation is probably due to the fact that inputs of $\mathrm{N}$ compounds were mainly from freshwater sources (Seitzinger et al. 2005; Yang et al. 2016). During ebb tide high amounts of freshwater, which contains high level of nutrient, are flushed out from the estuary. The contrast is true during high water when the incoming flow of saline water with low concentration of $\mathrm{N}$ compounds may dilute the nutrient content. This observation is similar 


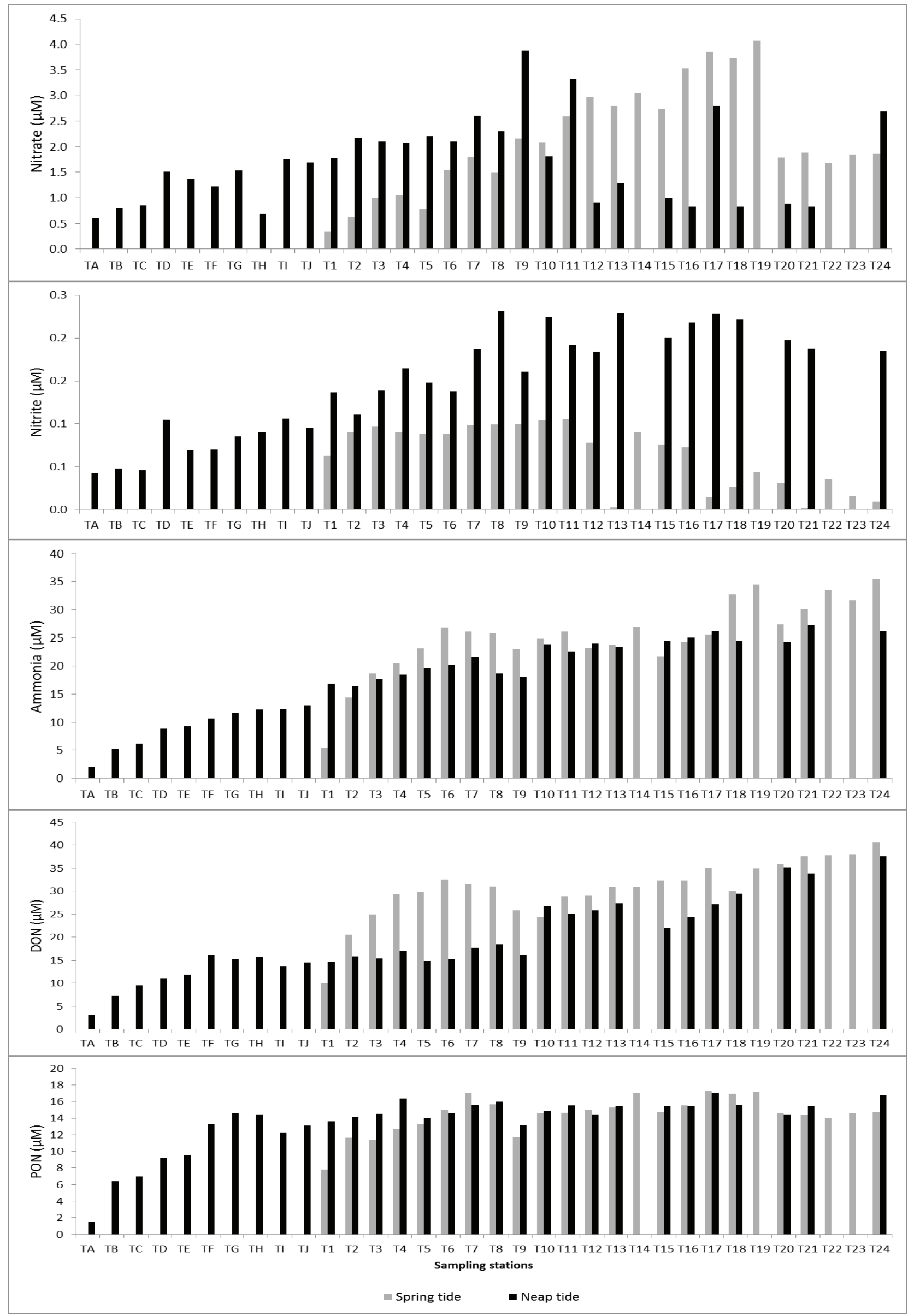

FIGURE 2. Variations in N compounds concentrations in the Sungai Terengganu estuary 


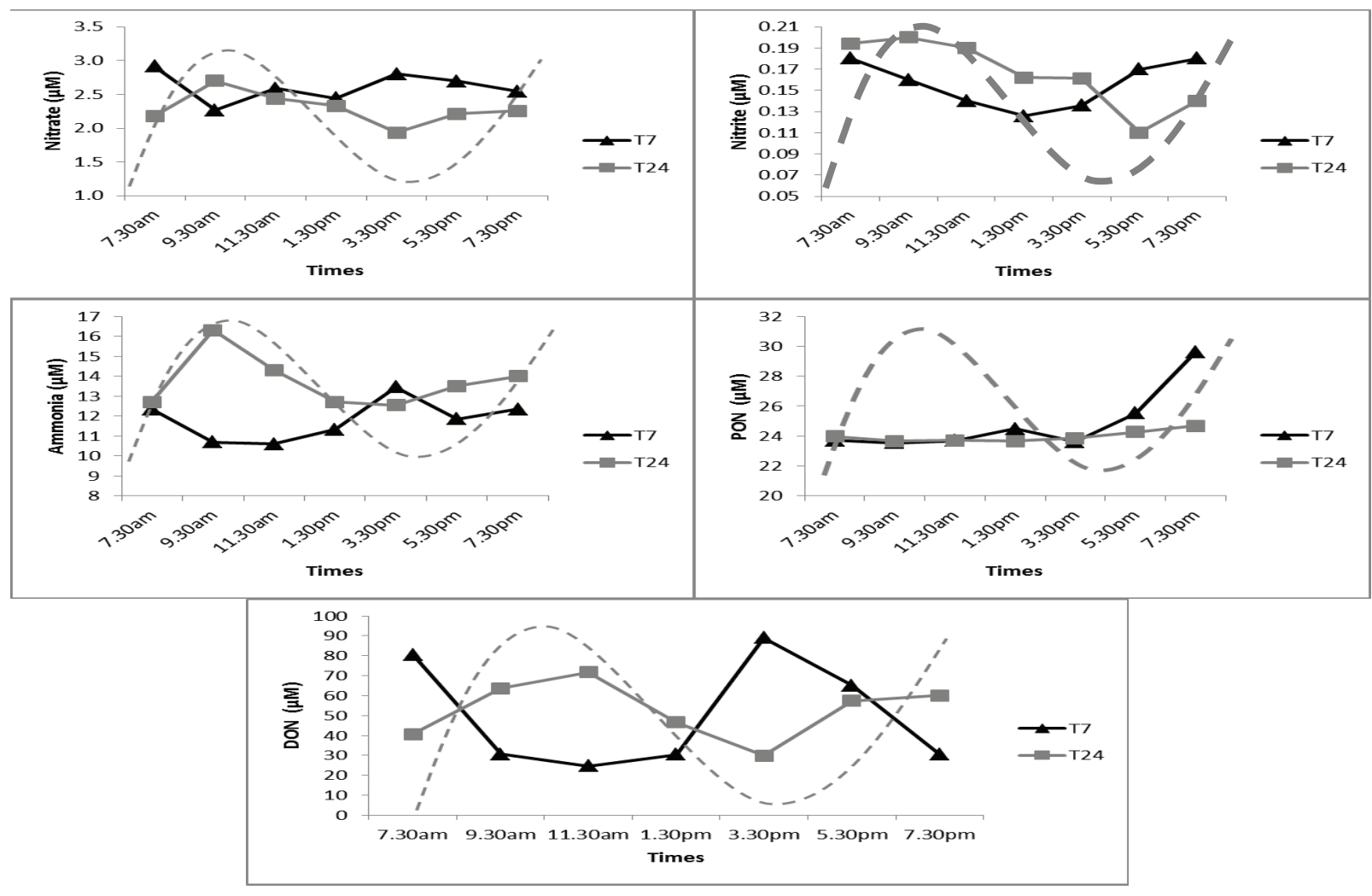

a) Spring tide

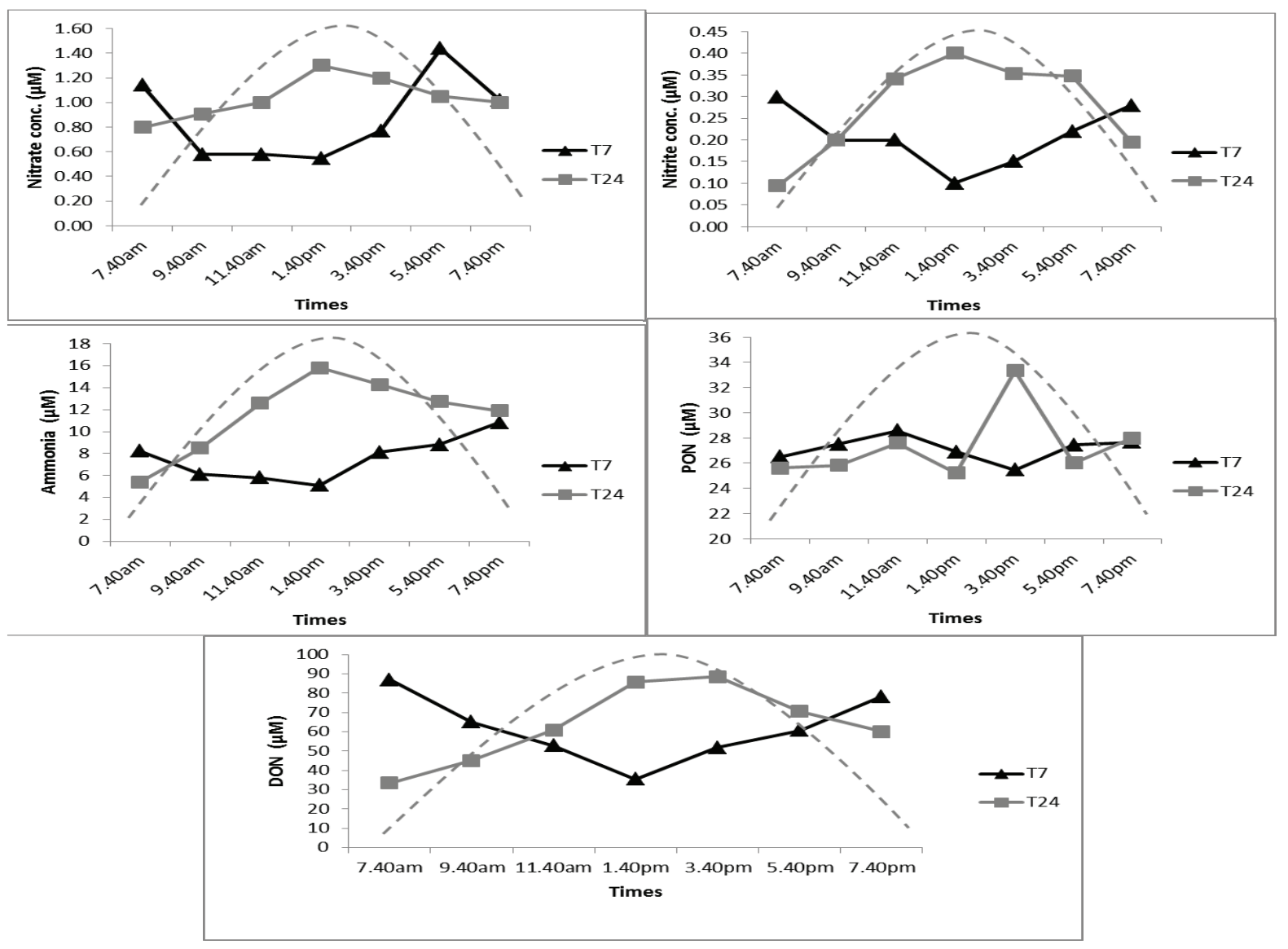

b) Neap tide

FIGURE 3. Nutrient concentrations from the $12 \mathrm{~h}$ diurnal survey during a) spring tide and $\mathrm{b}$ ) neap tide *Dashed lines show the tidal variations (not to scale) 


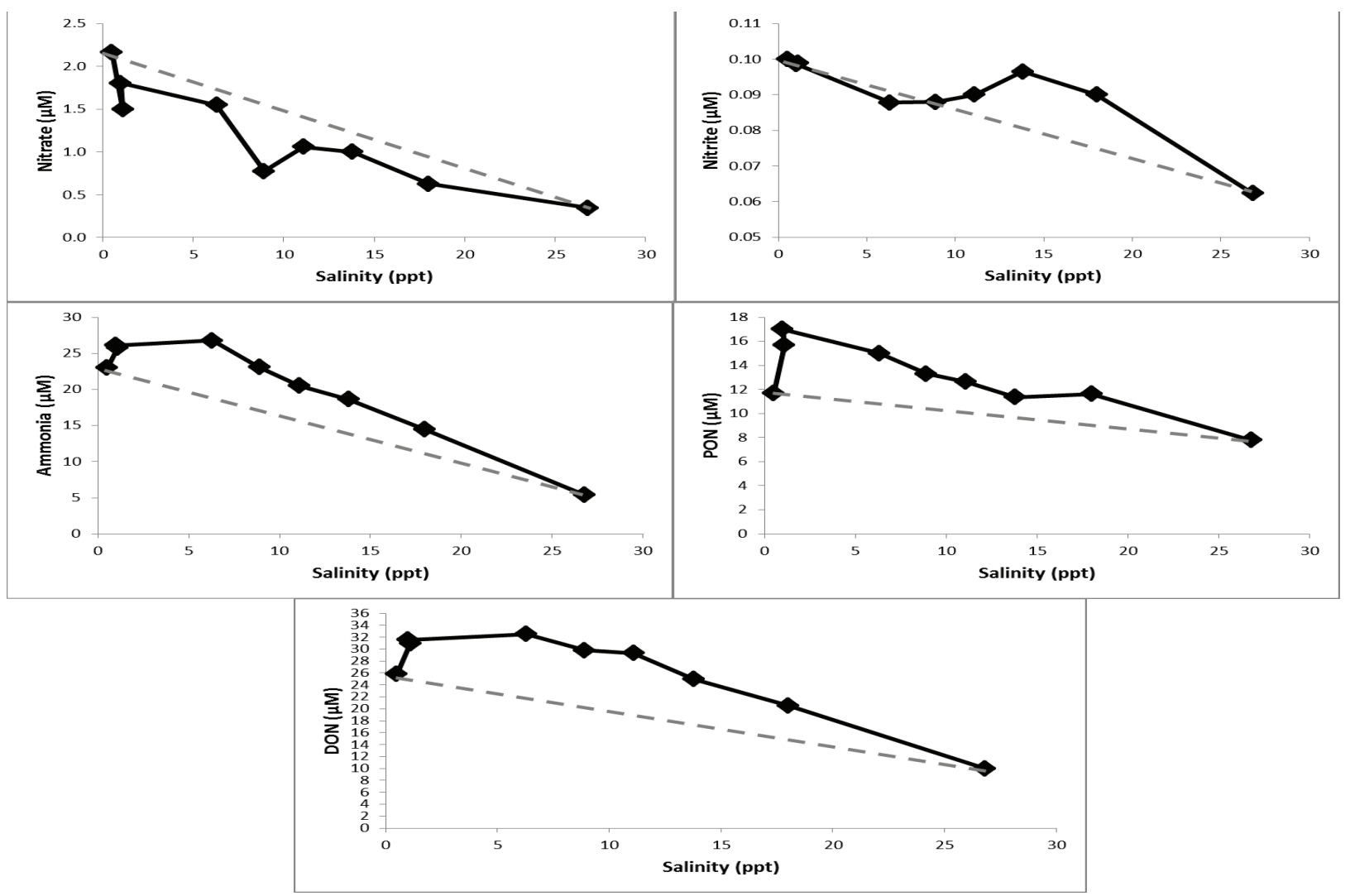

a) Spring tide

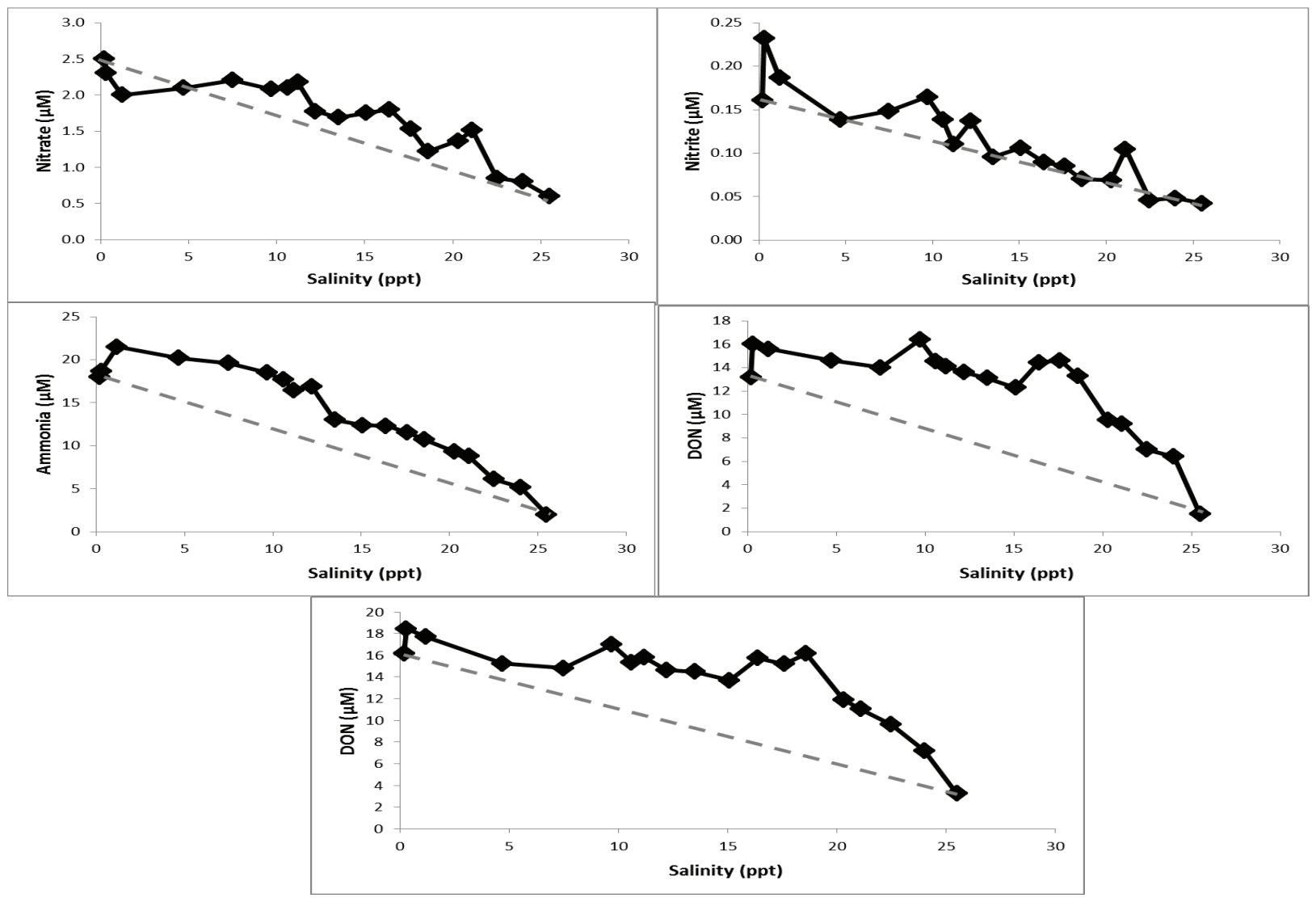

b) Neap tide

FIGURE 4. Variations in N compounds concentrations with salinity during a) spring tide and b) neap tide in the Sungai Terengganu estuary 
to that obtained during the longitudinal survey where the concentration range of nitrate, ammonia, DON and PON during spring tide were higher compared to during neap tide. The contrary was observed for nitrites, which is consistent with the observation during the longitudinal survey. No possible reason could be given to explain this which needs for further study. Therefore, this diurnal profile provides a clear evidence to support the fact that the concentration of $\mathrm{N}$ compounds in the TRE is strongly influenced by tidal changes.

\section{BEHAVIOUR OF N COMPOUNDS IN TRE}

Figure 4 shows the variation of $\mathrm{N}$ compounds across the salinity gradients during the estuarine mixing. The results obtained demonstrate a non-conservative behaviour shown by most of the parameters measured in both surveys. Only nitrates showed a removal trend during spring tide whereas the other nutrients showed addition during the mixing. The additional source of $\mathrm{N}$ compounds could be affected by anthropogenic activities such as direct disposal of domestic sewage and runoff (from urban areas, fish landings, boat manufacturing, market and tourism in Kuala Terengganu), which flow into the low and middle salinity regions of TRE. Previous studies by Jan (2002), Suratman et al. (2012) and Theivanan (2009) indicated that anthropogenic activities in the TRE may lead to high nutrient concentration in the surface water. In addition, Jickells et al. (2014) also found that the TRE was impacted by secondary sources (e.g. sewage input) which may encourage the non-conservative behaviour of the nutrients.

Other studies also found that anthropogenic activities contribute to the non-conservative behaviour with an addition of $\mathrm{N}$ compounds in their study area such as in the Sungai Dungun estuary, Malaysia (Tahir et al. 2008), Danshuei estuary, Taiwan (Wen et al. 2008), Changjiang estuary, China (Chen et al. 2010) and Wanquan River estuary, China (Li et al. 2013). In contrast, nitrate removal may occur in the water column during spring tide, possibly due to chemical processes taking place in the estuary through the denitrification process. This observation is supported by the pronounced removal of DO concentration (Figure 5) and addition of ammonia in the water column at the same tidal condition. Denitrification is the process of direct reduction of the oxide forms of nitrogen compounds to ammonia during low DO content. Denitrification process has been cited widely as a possible mechanism for nitrate removal during estuarine mixing. This has been documented for the Elbe estuary in Germany (Dahnke et al. 2008), the Humber estuary in England (Neal et al. 2008), the Wenjiaohe estuary in China (Liu et al. 2011) and the Qishon estuary in Israel (Eliani et al. 2013).

\section{COMPARISON WITH PREVIOUS STUDY}

Data obtained during this study was compared with results from a previous study carried out around the same study area by Theivanan (2009) (Table 1). Her study was performed prior to construction of the breakwater at the river mouth in 2010 during ebb neap and spring tides. The concentrations of nitrite and ammonia recorded during this study are relatively higher than those reported previously. This is probably due to the increase in anthropogenic activities at the surrounding areas and the presence of the breakwater. The nitrite and ammonia derived from the upstream areas are not able to accumulate in the estuary and these nutrients are not able to be completely flushed out to the open sea due the presence of the breakwater. Thus, both nutrients are trapped and accumulate in the inner part of the estuary. In contrast, the nitrate concentration recorded for the present study was relatively lower than reported by Theivanan (2009). No possible reason could be given to explain this situation because higher concentration of nitrate should also be observed as the breakwater would restrict the flow of water downstream.
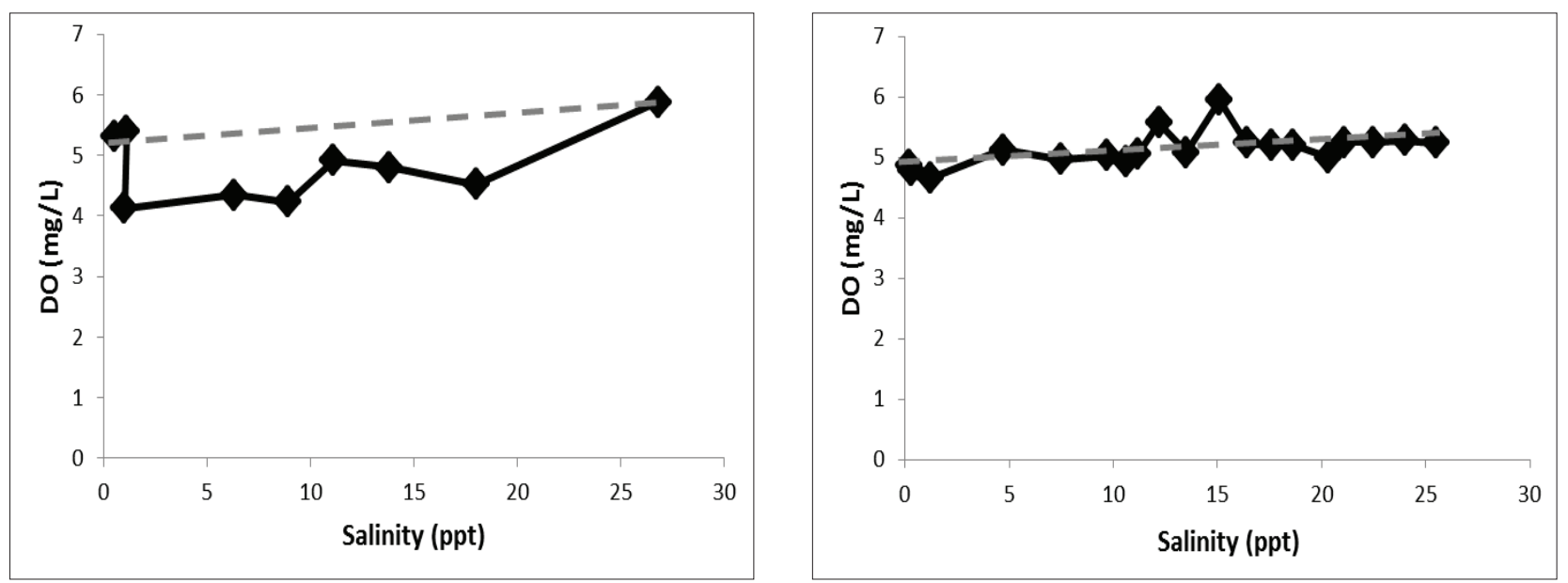

a) Spring tide b) Neap tide

FIGURE 5. Variation in dissolved oxygen concentrations with salinity during a) spring tide and b) neap tide in the Sungai Terengganu estuary (Salum 2015) 
TABLE 1. Comparison with the results from an earlier study (Theivanan 2009)

\begin{tabular}{lll}
\hline \multicolumn{1}{c}{ Parameter } & \multicolumn{1}{c}{ Present study } & \multicolumn{1}{c}{ Previous study } \\
\hline Nitrite $(\mu \mathrm{M})$ & $0.02-0.23(0.11 \pm 0.06)$ & $0.05-0.14(0.08 \pm 0.03)$ \\
Nitrate $(\mu \mathrm{M})$ & $0.3-4.7(1.9 \pm 0.9)$ & $12.0-103.9(43.4 \pm 24.4)$ \\
Ammonia $(\mu \mathrm{M})$ & $2.0-35.4(21.0 \pm 7.8)$ & $0.015-0.037(0.02 \pm 0.01)$ \\
DON $(\mu \mathrm{M})$ & $3.2-40.6(24.3 \pm 9.4)$. & Not determined \\
PON $(\mu \mathrm{M})$ & $1.5-11.8(13.9 \pm 2.9)$ & Not determined \\
\hline
\end{tabular}

()$=$ Mean \pm SD

\section{CONCLUSION}

The present study showed the consistent results between longitudinal and diurnal surveys, which show that $\mathrm{N}$ compounds in the surface waters $(\sim 0.5 \mathrm{~m})$ are higher during spring tide compared to neap tide. Only nitrite shows higher level during neap tide. The results also showed that significantly higher nutrient concentration is found upstream which suggests that $\mathrm{N}$ compounds are derived from freshwater inputs. In addition, the $\mathrm{N}$ compounds behave non-conservatively during mixing in TRE. This study also showed that tides play a major role in controlling the variation of $\mathrm{N}$ compounds in TRE.

\section{ACKNOWLEDGEMENTS}

This study was supported by grant awarded by National Hydraulic Research Institute of Malaysia (NAHRIM) (Vote No. 53112) and by the Higher Institution Centre of Excellence (HICoE) Research Grant (Vote No. 66928).

\section{REFERENCES}

Anand, S.S., Anju, K.J., Mathew, D. \& Kumar, M.D. 2014. Subhourly changes in biogeochemical properties in surface waters of Zuari estuary, Goa. Environmental Monitoring and Assessment 186: 719-724.

Bukaveckas, P.A., Barry, L.E., Beckwith, M.J., David, V. \& Lederer, B. 2011. Factors determining the location of the chlorophyll maximum and the fate of algal production within the tidal freshwater James River. Estuaries and Coasts 34: 569-582.

Chen, H., Yu, Z., Yao, Q., Mi, T. \& Liu, P. 2010. Nutrient concentrations and fluxes in the Changjiang Estuary during summer. Acta Oceanologica Sinica 29: 107-119.

Chen, Y., Liu, R., Sun, C., Zhang, P., Feng, C. \& Shen, Z. 2012. Spatial and temporal variations in nitrogen and phosphorous nutrients in the Yangtze River Estuary. Marine Pollution Bulletin 64: 2083-2089.

Dahnke, K., Bahlmann, E. \& Emeis, K. 2008. A nitrate sink in estuaries? An assessment by means of stable nitrate isotopes in the Elbe estuary. Limnology and Oceanography 53: 1504-1511.

Driscoll, C.T., Chen, C.Y., Hammerschmidt, C.R., Mason, R.P., Gilmour, C.C., Sunderland, E.M., Greenfield, B.K., Buckman, K.L. \& Lamborg, C.H. 2012. Nutrient supply and mercury dynamics in marine ecosystems: A conceptual model. Environmental Research 119: 118-131.

Eliani-Russak, E., Herut, B. \& Sivan, O. 2013. The role of highly sratified nutrient-rich small estuaries as a source of dissolved inorganic nitrogen to coastal seawater, the Qishon (SE Mediterranean) case. Marine Pollution Bulletin 71: 250-258.
Garcia, J.C., Ketover, R.D.J., Loh, A.N., Parsons, M.L. \& Urakawa, H. 2014. Influence of freshwater discharge on the microbial degradation processes of dissolved organic nitrogen in a subtropical estuary. Antonie van Leeuwenhoek 107: 613-632.

Gianesella, S.M.F., Saldanha-Corrêa, F.M.P., Miranda, L.B., De Corrêa, M.A. \& Moser, G.A.O. 2005. Short-term variability and transport of nutrients and Chlorophyll-a in Bertioga Channel, São Paulo State, Brazil. Brazilian Journal of Oceanography 53: 99-114.

Gilbert, M., Needoba, J., Koch, C., Barnard, A. \& Baptista, A. 2013. Nutrient loading and transformations in the Columbia River estuary determined by high-resolution in situ sensors. Estuaries and Coasts 36: 708-727.

Grasshoff, K., Ehrhardt, M. \& Kremling, K. 1983. Methods of Seawater Analysis. 2nd ed. Florida: Verlag Chemie. p. 419.

Ismail, W.R. \& Ibrahim, M.N. 2015. An assessment of sediment and nitrogen input into the upper Merbok estuary, Kedah, Malaysia. Water Quality, Exposure and Health 7: 79-88.

Jan, J.K. 2002. Distribution and fluxes of dissolved carbon, nitrogen and phosphorus in Terengganu River estuary. Thesis of Degree of Master Science, Universiti Putra Malaysia. p. 140 (Unpublished).

Jickells, T.D., Andrews, J.E., Parkes, D.J., Suratman, S., Aziz, A.A. \& Hee, Y.Y. 2014. Nutrient transport through estuaries: The importance of the estuarine geography. Estuarine, Coastal and Shelf Science 150: 215-229.

Li, R., Liu, S., Zhang, G., Ren, J. \& Zhang, J. 2013. Biogeochemistry of nutrients in an estuary affected by human activities: The Wanquan River estuary, eastern Hainan Island, China. Continental Shelf Research 57: 18-31.

Liss, P.S. 1976. Conservative and non-conservative behaviour of dissolved constituents during estuarine mixing. In Estuarine Chemistry, edited by Burton, J.D. \& Liss, P.S. London: Academic Press. p. 229.

Liu, S.M., Li, R.H., Zhang, G.L., Wang, D.R., Du, J.Z., Herbeck, L.S. \& Ren, J.L. 2011. The impact of anthropogenic activities on nutrient dynamics in the tropical Wenchanghe and Wenjiaohe Estuary and Lagoon system in East Hainan, China. Marine Chemistry 125: 49-68.

Neal, C., Davies, H. \& Neal, M. 2008. Water quality, nutrients and the water framework directive in an agricultural region: The lower Humber Rivers, northern England. Journal of Hydrology 350: 232-245.

Pasquer, B., Mongin, M., Johnston, N. \& Wright, S. 2010. Distribution of particulate organic matter (POM) in the Southern Ocean during BROKE-West $\left(30^{\circ} \mathrm{E}-80^{\circ} \mathrm{E}\right)$. DeepSea Research Part II: Topical Studies in Oceanography 57: 779-793.

Ryther, J.H. \& Dunstan, W.M. 1971. Nitrogen, phosphorus and eutrophication in the coastal marine environment. Science 171: 1008-1112.

Salum, S.S. 2015. Distribution and behaviour of phosphorus- and silicate-based nutrients with respect to tidal variation in the 
surface water of the Terengganu River estuary. Thesis of Degree of Master Science, Universiti Malaysia Terengganu. pp. 83-84 (Unpublished).

Seitzinger, S.P., Harrison, J.A., Dumont, E., Beusen, A.H.W. \& Bouwman, A.F. 2005. Sources and delivery of carbon, nitrogen, and phosphorus to the coastal zone: An overview of Global NEWS models and their application. Global Biogeochemical Cycles 19. http://dx.doi. org/10.1029/2005GB002606 (GB4S01).

Senthilkumar, B., Purvaja, R. \& Ramesh, R. 2008. Seasonal and tidal dynamics of nutrients and chlorophyll a in a tropical mangrove estuary, southeast coast of India. Indian Journal of Marine Sciences 37: 132-140.

Shaha, D.C., Cho, Y.K., Seo, G.H., Kim, C.S. \& Jung, K.T. 2010. Using flushing rate to investigate spring-neap and spatial variations of gravitational circulation and tidal exchanges in an estuary. Hydrology and Earth System Sciences 14: 1465-1476.

Sharples, J., Tweddle, J.F., Mattias Green, J.A., Palmer, M.R., Kim, Y.N., Hickman, A.E., Holligan, P.M., Moore, C.M., Rippeth, T.P., Simpson, J.H. \& Krivtsov, V. 2007. Springneap modulation of internal tide mixing and vertical nitrate fluxes at a shelf edge in summer. Limnology and Oceanography 52: 1735-1747.

Statham, P.J. 2012. Nutrients in estuaries - An overview and the potential impacts of climate change. Science of the Total Environment 434: 213-227.

Suratman, S., Che Zan, N.H. \& Mohd Tahir, N. 2012. A dissolved and particulate $\mathrm{Zn}$ in Terengganu River estuary, Southern South China Sea (Malaysia). Journal of Sustainability Science and Management 7: 124-127.

Suratman, S., Weston, K., Greenwood, N., Sivyer, D.B., Pearce, D.J. \& Jickells, T. 2010. High frequency measurements of dissolved inorganic and organic nutrients using instrumented moorings in the southern and central North Sea. Estuarine, Coastal and Shelf Science 87: 631-639.

Suratman, S., Jickells, T., Weston, K. \& Fernand, L. 2008. Seasonal variability of inorganic and organic nitrogen in the North Sea. Hydrobiologia 610: 83-98.

Tahir, N.M., Suratman, S., Shazili, M.A.M., Ariffin, M.M., Amin, M.S.M. \& Ariff, N.F.M.N.I. 2008. Behaviour of water quality parameters during ebb tide in Dungun River estuary, Terengganu. Journal of Sustainability Science and Management 3: 1-10.
Theivanan, G. 2009. A Preliminary study on the distribution of nitrogen compounds in Terengganu River estuary. Thesis of Degree of Bachelor Science. Universiti Malaysia Terengganu. p. 50.

Wen, L.S., Jiann, K.T. \& Liu, K.K. 2008. Seasonal variation and flux of dissolved nutrients in the Danshuei Estuary, Taiwan: A hypoxic subtropical mountain river. Estuarine, Coastal and Shelf Science 78: 694-704.

Yang, X., Lin, Q., Fu, G., He, Y., Luo, X. \& Zheng, Z. 2016. Spatiotemporal patterns and source attribution of nitrogen load in a river basin with complex pollution sources. Water Research 94: 187-199.

Suhaimi Suratman*, Azyyati Abdul Aziz \& Norhayati Mohd Tahir Institute of Oceanography and Environment Universiti Malaysia Terengganu 21030 Kuala Nerus, Terengganu Darul Iman Malaysia

\section{Suhaimi Suratman*}

Institute of Tropical Biodiversity and Sustainable Development Universiti Malaysia Terengganu

21030 Kuala Nerus, Terengganu Darul Iman

Malaysia

Norhayati Mohd Tahir

School of Marine and Environment Sciences

Universiti Malaysia Terengganu

21030 Kuala Nerus, Terengganu Darul Iman

Malaysia

Lee Hin Lee

Water Quality and Environment Research Centre

National Hydraulic Research Institute for Malaysia

43300 Seri Kembangan, Selangor Darul Ehsan

Malaysia

*Corresponding author; email: miman@umt.edu.my

Received: 30 December 2016

Accepted: 27 October 2017 
